\title{
PENGARUH KEDISIPLINAN DAN METODE MENGAJAR GURU TERHADAP HASIL BELAJAR PESERTA DIDIK PADA MATA PELAJARAN SOSIOLOGI DI MAN 1 SITUBONDO
}

\author{
Mohammad Sudarwanto ${ }^{1}$, Nur salam², Arif Sholihin ${ }^{3}$ \\ 1,2, ${ }^{3}$ Program Studi Pendidikan IPS Ekonomi, STKIP PGRI Situbondo \\ Email:mohammad.sudarwanto14@gmail.com
}

\begin{abstract}
Abstrak
Penelitian ini bertujuan untuk mengetahui adanya pengaruh kedisiplinan guru dan metode mengajar guru terhadap hasil belajar peserta didik.Kedisiplinan guru mencakup berbagai macam pengaruh yang ditujukan untuk mendidik peserta didik dalam disiplin belajar sekaligus memperlancar kerjanya.Sementara metode mengajar membantu mempermudah guru dan peserta didik untuk mendalami materi pelajaran dalam pembelajran.Penelitian ini menggunakan rancangan ex post facto.Subjek penelitian di MAN 1 Situbondo pada kelas XI IPS dengan 70 responden.Metode pengumpulan data pada peneletian ini menggunakan metode observasi, kuesioner, dokumen.Analisis data diperoleh menggunakan regrasi linier berganda dan uji t. Hasil penelitian ini adalah (1) terdapat pengaruh kedisiplinan guru terhadap hasil belajar peserta didik.Dikarenakan nilai tingkat signifikansi sebesar $0.000<0.05$. Hal ini berarti bahwa terdapat pengaruh yang signifikan antara kedisiplinan guru terhadap hasil belajar peserta didik. (2) terdapat pengaruh metode mengajar guru terhadap hasil belajar peserta didik.Dikarenakan nilai tingkat signifikansi sebesar $0.001<0.05$. Hal ini berarti bahwa terdapat pengaruh yang signifikan antara metode mengajar guru terhadap hasil belajar peserta didik.Sehingga dapat disimpulkan bahwa kedisiplinan dan metode mengajar guru secara simultan memiliki pengaruh yang signifikan terhadap hasil belajar peserta didik.
\end{abstract}

Kata Kunci: Kedisiplinan guru, metode mengajar guru, dan hasil belajar

\begin{abstract}
This study aims to determine the influence of teacher discipline and teacher teaching methods on student learning outcomes. Teacher discipline includes a variety of influences aimed at educating students in the discipline of learning while expediting their work. While teaching methods help facilitate teachers and students to explore material lessons in learning. This research uses the ex-post facto design. Research subject at MAN 1 Situbondo in class XI IPS with 70 respondents. The data collection method in this study uses the method of observation, questionnaire, document. Data analysis is obtained using multiple linear regression and t-test. The results of this study are (1) there is an effect of teacher discipline on student learning outcomes. Due to the significance level of $0.000<0.05$. This means that there is a significant influence between teacher discipline on student learning outcomes. (2) there is an influence of teacher teaching methods on student learning outcomes. Because the significance level value is $0.001<0.05$. This means that there is a significant influence between the teaching methods of teachers on student learning outcomes. So it can be concluded that discipline and teaching methods simultaneously have a significant influence on student learning outcomes.
\end{abstract}

Keywords: teacher discipline, teacher teaching methods, and learning outcomes 


\section{PENDAHULUAN}

Proses belajar mengajar merupakan interaksi yang terjadi antara guru dan peserta didik dalam proses pembelajaran yang sedang berlangsung dengan jangka waktu yang ditentukan selama waktu mengajar maupun belajar yang berlangsung di dalam kelas.

Menurut Husamah (2016) Belajar merupakan suatu aktivitas mental dan psikisyang berlangsung dalam interaksi aktif dengan lingkungan danmenghasilkan perubahan dalam pengetahuan dan pemahaman,keterampilan serta nilai-nilai, dan sikap.

Guru sebagai pengajar merupakan sesuatu yang dipandang mulia dalam dunia pendididkan. Hal tersebut menunjukkan bahwa tugas seorang guru memiliki tanggung jawab yang sangat besar dalam mendidik peserta didik menuju ke arah yang dicitacitakannya.Dalam mencapai hal tersebut perlu adanya usaha yang keras untuk menjadi yang berkualitas.Untuk mengetahuinya dapat dilihat dari hasil belajar peserta didik.

Menurut Maruya (2016) Hasil belajar adalah suatu kemampuan peserta didik dalam penguasaan mata pelajaran yang diberikan oleh guru pada satu semester atau satu tahun ajaran. Hasil belajar tersebut biasanya diukur dengan nilai hasil belajar peserta didik setelah guru memberikan test evaluasi terhadap peserta didik. Hasil belajar adalah nilai akhir yang diproleh peserta didik setelah melalui beberapa test dalam proses pembelajaran.

Guru harus memberikan arahan yang baik kepada peserta didik dan juga menjadi contoh teladan yang gampang ditiru bagi peserta didik. Salah satunya adalah kedisiplinan guru.Kedisiplinan adalah sikap ketaatan seseorang pada peraturan baik itu berupa tata tertib maupun norma-norma yang belaku di sekolah.

Menurut Sujarwanto (2013) Kedisiplinan adalah suatu kondisi yang tercipta dan terbentuk melalui proses dari serangkaian perilaku yang menunjukkan nilai-nilai ketaatan, kepatuhan, kesetiaan, keteraturan dan atau ketertiban. Setiap guru harus mematuhi peraturan yang telah dibuat oleh sekolah dan guru harus bertanggung jawab atas tugas yang diembannya.Seorang guru harus memberi contoh disiplin bagi peserta didik.Guru juga harus menanamkan pola kedisiplin pada peserta didik dalam disiplin waktu, sikap maupun dalam mengajar dan pemberian tugas pada peserta didik.

Selain kedisiplinan, peneliti akan menggunakan metode mengajar ebagai media pembanding. Menurut Khasanah (2012) Metode Mengajar Guru adalah proses peserta didik menangkap dan menanggapi cara atau metode yang digunakan guru dalam menyampaikan materi pelajaran kepada peserta didik. Metode mengajar adalah cara yang digunakan guru untuk mengaplikasikan rencana yang sudah disusun dalam kegiatan yang nyata untuk menyampaikan materi pelajaran agar lebih terarah dengan tujuan pembelajaran yang kondusif, efektif, dan efisien dalam proses kegiatan belajar mengajar.

Guru sebagai salah satu komponen dalam proses belajar mengajar merupakan pemegang peran sangat penting. Guru bukan hanya sekedar menyampaikan materi saja, tetapi lebih dari itu guru dapat dikatakan sebagai sentral pembelajaran. Sebagai pengatur sekaligus pelaku dalam proses belajar mengajar, gurulah yang mengarahkan bagaimana 
proses belajar mengajar itu dilaksanakan. Karena itu guru harus dapat membuat suatu pengajaran yang lebih efektif juga menarik sehingga bahan pelajaran yang disampaikan akan membuat peserta didik merasa senang dan tidak bosan saat pelajaran berlangsung.

Menurut Ishlacha (2012) berpendapat bahwa Kedisiplinan berasal dari kata disiplin yang artinya kepatuhan untuk menghormati dan melaksanakan suatu sistem yang mengharuskan seseorang untuk tunduk dan patuh pada keputusan, perintah atau peraturan yang berlaku. Pernyataan yang serupa diungkap oleh Maruya (2016) Disiplin guru adalah menaati dan mematuhi semua peraturan dan tata tertib yang telah dibuat oleh sekolah tersebut dan tidak melanggarkan aturan-aturan yang telah ada.Kedisiplinan berkenaan dengan kepatuhan dan ketaatan seseorang atau kelompok orang terhadap norma-norma dan peraturan-peraturan yang berlaku secara tertulis. Kedisiplinan dibentukmelalui latihan dan pendidikan sehingga terbentuk kesadaran dan keyakinan dalam dirinya untuk berbuat tanpa paksaan.

Kedisiplinan guru adalah cara guru dalam membagi waktu antara mengajar maupun memberi tugas pada peserta didik dan menata sikap diri guru sebagai contoh untuk diguguh dan ditiru oleh peserta didik dalam menata sikap peserta didik dalam proses belajar mengajar. Guru juga dituntut untuk selalu aktif dalam melaksanakan pembelajaran termasuk menanya dan bertanya untuk membangun suasana yang aktif dan mengembangkan ilmu pengetahuan dan pemahaman peserta didik dalam proses kegiatan belajar mengajar.

Kedisiplinan guru dibagi menjadi 3 indikator. (1) Disiplin waktu, berkenaan dengan ketepatan waktu guru dalam memasukin ataupun meninggalkan kelas sesuai dengan jadwal jam yang sudah ditentukan. (2) Disiplin sikap, cara guru dalam mendidik dan memberi contoh dengan bersikap ramah dan tegas dengan tujuan menunjukkan sikap untuk saling menghormati antar sesama guru ataupun dengan peserta didik. (3) Disiplin mengajar, berkenaan tentang guru dalam disiplin mengisi jam pelajaran tanpa meninggalkan kelas dengan pengecualian ada hal penting yang mengharuskan guru untuk meninggalkan kelas.

Sebagai media pembanding Peneliti menggunakan metode mengajar.Septiana (2016) berpendapat Metode digunakan untuk merealisasikan strategi yang telah ditetapkan.keberhasilan implementasi strategi mengajar sangat tergantung pada cara guru dalam menggunakan metode mengajar, karena suatu strategi mengajar hanya mungkin dapat diimplementasikan melalui penggunaan metode mengajar.

Kemudian Yulinda (2016) berpendapat bahwa Tujuan pembelajaran akan dapat dicapai dengan penggunaan metode yang tepat, sesuai dengan standar keberhasilan yang terdapat di dalam suatu tujuan. Strategi atau metode yang dapat digunakan dalam kegiatan belajar mengajar bermacam-macam penggunaannya tergantung dari rumusan tujuan.Metode mengajar guru adalah teknik penyajian yang digunakan oleh guru untuk mengajar atau menyajikan bahan pelajaran kepada peserta didik di dalam kelas agar pelajaran tersebut ditangkap, dipahami, dan digunakan oleh peserta didik dengan baik.

Metode mengajar guru dibagi menjadi 3 indikator. (1) Menurut Sriyadi (2013) Metode tanya jawab adalah cara penyajian pelajaran dalam bentuk pertanyaan yang 
harus dijawab, terutama dari guru kepada peseta didik, tetapi dapat pula dari peseta didik kepada guru. Metode tanya jawab memungkinkan terjadinya komunikasi langsung yang bersifat dua arah sebab pada saat yang sama terjadi dialog antara guru dan peseta didik.

Menurut Akbar (2014) Metode Tanya jawab adalah metode mengajar yang memungkinkan terjadinya komunikasi langsung yang bersifat two waytraffic sebab pada saat yang sama terjadi dialog antara guru dan peseta didik. Guru bertanya peseta didik menjawab, atau peseta didik bertanya guru menjawab. Metodetanyajawab adalah cara penyajian pelajaran dalam bentuk pertanyaan yang harus dijawab, terutama dari guru kepada peseta didik, tetapi dapat pula dari peseta didik kepada guru.

Hal ini dilakukan dengan cara pengajuan-pengajuan pertanyaan yang mengarahkan peseta didik untuk memahami materi pelajaran dalam rangka mencapai tujuan pembelajaran. (2) Menurt Saroh (2015) diskusi adalah kata yang berasal dari bahasa Latin yaitu "discussus" yang mempunyai arti memeriksa dan menyelidiki. Dalam pengertian umum diskusi adalah suatu proses yang melibatkan dua atau lebih individu yang berintegrasi secara varbal dan saling berhadapan muka mengenai tujuan atau sasaran yang sudah tertentu melalui cara tukar menukar infomasi, mempertahankan pendapat dan memacahkan masalah.

Metode diskusi adalah interaksi sosial yang terjadi antara peserta didik dan peserta didik atau peserta didik dengan guru, dimana peserta didik dihadapkan kepada suatu masalah yang bisa berupa pernyataan atau pertanyaan yang bersifat permaslahan untuk dibahas dan dipecahkan bersama. Guru memberi kesempatan kepada para peserta didik untuk mengadakan perbincangan ilmiah guna mengumpulkan data, pendapat dari masing-masing peserta didik, membuat kesimpulan, atau menyusun berbagai alternatif pemecahansuatu masalahdikarenakan dapat bertukar pendapat dan bekerja sama dalam menyelesaikan tugas dalam satu kelompok.

Metode diskusi adalah salah satu cara mendidik yang berupaya memecahkan masalah yang dihadapi, baik dua orang atau lebih yang masin-masing mengajukan argumentasinya untuk memperkuat pendapatnya.(3)Metode Penugasan menurut Akbar (2014) Tugas dan resitasi tidak sama dengan pekerjaan rumah, tetapi jauh lebih luas dari itu. Tugas bisa dilaksanakan di rumah, di sekolah, di perpustakaan, dan di tempatlainnya. Tugas dan resi- tasi merangsang anak untuk aktif belajar baik secara individual maupun secara kelompok.

Metode ini diberikan karena materi pelajaran banyak sementara waktu sedikit. Agar materi pelajaranselesai sesuai dengan waktu yang ditentukan, maka metode inilah yang biasanya digunakan oleh guru. Tugas ini biasanya bisa dilaksanakan di rumah, di sekolah, di perpustakaan, dan di tempat lainnya. Tugas dan resitasi merangsang anak untuk aktif belajar, baik individu maupun kelompok, tugas yang diberikan sangat banyak macamnya tergantung dari tujuan yang hendak dicapai.Metode Penugasan atau resitasi adalah cara guru memberi tugas kepada peseta didik dalam proses belajar mengajar. Tugas-tugas itu dapat berupa mengikhtisarkan karangan, (dari surat kabar, 
majalah atau buku bacaan) membuat kliping, mengumpulkan gambar, perangko, dan dapat pula menyusun karangan.

Hasil belajar untuk mengetahui hasil nilai yang diperoleh peserta didik setelah melalui berbagai tes dan evaluasi. Menurut Rosana (2014) dalam Nana Sudjana (2010:2), hasil belajar adalah seluruh kecakapan dan segala hal yang diperoleh melalui proses pembelajaran yang dinyatakan dengan angka dan diukur dengan tes hasil belajar. Dari pengertian tersebut dapat disimpulkan bahwa hasil belajar merupakan nilai atau angka yang diperoleh peserta didik setelah melewati beberapa test dalam proses belajar mengajar. Secara sederhana hasil belajar ini dapat diketahui setelah guru melakukan evaluasi kepada peserta didik.

Evaluasi merupakan salah satu kegiatan yang menjadi kewajiban bagi setiap guru. Evaluasi dilakuakan untuk dapat mengetahui informasi tentang kemajuan yang telah dicapai peserta didik, bagaimana dan sampai dimana kemampuan yang peserta didik dalam menguasai meteri pelajaran yang dipelajari. Kemudian dalam proses penilaian tidak hanya dilihat dari ranah kognitif saja melainkan secara keseluruhan baik afektif maupun psikomotorik. Menurut bloom dan k13 hasil belajar terdapat tiga aspek yang tidak dapat dipisahkan, diantaranya adalah kognitif, afektif dan psikomotorik. Ketiga aspek ini saling berkaitan dan tidak dapat di pisahkan.Namun dalam penelitian ini, peneliti menggunkan ranah kognitif sebagai perbandingan nilai yang didapat antara nilai Ulangan Harian dengan nilai angket.

Ranah kognitif adalah ranah yang mencakup kegiatan mental (otak). Segala upaya yang menyangkut aktivitas kemampuan berfikir yang mencakup kemampuan intelektual yang lebih sederhana, yaitu mengingat, sampai pada kemampuan memecahkan masalah yang menuntut peseta didik untuk menghubungakan dan menggabungkan beberapa ide, gagasan, metode atau prosedur yang dipelajari untuk memecahkan masalah tersebut.

Dengan demikian aspek kognitif adalah subtaksonomi yang mengungkapkan tentang kegiatan mental yang sering berawal dari tingkat mengingat sampai ke tingkat yang paling tinggi yaitu membuat atau mencipta.Hasil belajar ranah kognitif dapat diukur melalui tingkat pengetahuan dan pemahaman peseta didik terhadap isi materi yang di pelajari. Sederhananya adalah kemampuan guru dalam mengekspoitasi potensi peseta didik dengan melalui penilaian guru tentang kemampuan bertanya peseta didik dalam menyampaikan pendapat tetang materi yang dipelajari peseta didik saat proses belajar mengajar di dalam kelas.

Tujuan penelitian ini adalah untuk mengetahui adanya pengaruh kedisiplinan dan metode mengajar guru terhadap hasil belajar peserta didik pada mata pelajaran sosiologi kelas XI IPS di MAN Situbondo tahun pelajaran 2018/2019.

Hipotesis penelitian ini adalah 1) Ada pengaruh kedisiplinan guru (X1) terhadap hasil belajar peserta didik (Y) pada mata pelajaran sosiologi kelas XI IPS di MAN 1 Situbondo, 2)Ada pengaruh metode mengajar guru (X2) terhadap hasil belajar peserta didik (Y) pada mata pelajaran sosiologi kelas XI di IPS MAN 1 Situbondo. 


\section{METODE PENELITIAN}

Rancangan penelitian yang diguanakan adalah ex post facto yang merupakan penelitian dimana variabel-variabel bebas telah terjadi ketika peneliti mulai dengan variabel terikat dalam suatu penelitian. ex post facto merupakan suatu penelitian yang dilakukan untuk meneliti peristiwa yang telah terjadi dan kemudian merunut kebelakang untuk mengetahui faktor-faktor yang menyebabkan timbulnya kejadian tersebut Khasanah.dkk (2012) dalam (Sugiyono, 2008:26). Pada penelitian ini keterkaitan antara variabel bebas dengan variabel bebas maupun vaiabel bebas dengan variabel terikat. Penelitian ini bersifat korelasi karena mencari pengaruh antara dua variabel atau lebih yaitu variabel bebas dan terikat.Dalam penelitian ini peneliti ingin mengetahui apakah ada pengaruh kedisiplinan dan metode mengajar guru terhadap hasil belajar peserta didik.

Daerah penelitiaan berarti tempat dilaksanakannya penelitian dan perlu ditetatapkan tidak bisa dilaksanakan disembarang tempat. Daerah penelitian ini akan dilaksanakan di MAN 1 Situbondo.Penentuan daerah tersebut memenuhi syarat untuk dijadikan objek penelitian.Penentuan responden pada penelitian ini menggunakan metode proporsional random sampling. Menurut (Sugiyono, 2010: 82 ) random sampling adalah teknik pengambilan anggota sample dari populasi dilakukan secara acak tanpa memerhatikan strata yang ada dalam populasi itu. Untuk mengetahui responden salah satunya dengan cara mengetahui populasi dan sampel yang akan teliti.Dari jumlah peserta didik kelas XI IPS terdiri dari 3 kelas sebanyak 70 peserta didik yang kemudian diambil dengan cara undian, perhitungan penentuan responden penelitian dapat dilihat pada tabel berikut:

Tabel 3.1 Jumlah sampel Responden Penelitian

\begin{tabular}{|c|c|c|c|}
\hline No. & Kelas & Populasi & Jumlah Responden Tiap Kelas \\
\hline 1 & X IPS 1 & 20 & $\frac{\mathbf{2 0}}{\mathbf{7 0}} \times 70=20$ Peserta Didik \\
\hline 2 & X IPS 2 & 25 & $\frac{\mathbf{2 5}}{\mathbf{7 0}} \times 70=25$ Peserta Didik \\
\hline 3 & X IPS 3 & 25 & $\frac{\mathbf{2 5}}{\mathbf{7 0}} \times 70=25$ Peserta Didik \\
\hline \multicolumn{2}{|c|}{ Jumlah } & 70 & 70 Peserta Didik \\
\hline
\end{tabular}

Pengumpulan data dalam penelitian ini menggunakan observasi, kuesioner, dan dokumen. Pertanyaan pada angket sebanyak 60 soal di berikan kepada responden untuk menjawab pertanyaan yang telah disediakan. Hasil nilai angket yang telah di isi kemudian dibandingkan dengan hasil nilai ulangan harian peserta didik untuk mengetahui pengaruh variabel $\mathrm{X}$ terhadap variabel Y pada penelitian ini. Sebelum soal di bagikan kepada para responden angket terlebih dahulu di lakukan uji validitas dan reliabilitas instrumen penelitian.

Validitas adalah suatu ukuran yang menunjukan tingkat kevalidan atau kesahihan suatu instrumen.Validitas berarti alat ukur dengan apa yang hendak diukur, artinya alat ukur yang digunakan dalam pengukuran dapat digunakan untuk mengukur apa yang hendak diukur. 
Reliabilitas merupakan ukuran sejauh mana suatu alat ukur dapat memberikan gambaran yang benar-benar dipercaya tentang kemampuan seseorang.Tujuan reliabilitas adalah untuk mengetahui apakah data yang sudah terkumpul dapat dipercaya atau tidak.Data yang terkumpul kemudian akan dianalisis menggunakan uji regresi linier berganda dan uji T menggunakan programa aplikasi SPSS Version 25 for Window.

\section{HASIL DAN PEMBAHASAN}

Dari keterangan diatas bahwasanya sebelum soal angket di berikan kepada responden, angket terlebih dahulu di uji validitas dan reliabilitaskan.Dan hasilnya 40 soal valid dan reliabel.Setelah dilakukan validitas dan reliabel soal angket di berikan kepada responden dan hasil nilai yang di dapat kemudian di uji menggunakan regresi linier berganda dan uji $\mathrm{T}$ Perhitungan tersebut dimaksudkan untuk membuktikan hipotesa kerja mayor dengan menggunakan uji signifkansi antara lain sebagai berikut:

\begin{tabular}{|c|c|c|c|c|c|c|}
\hline \multicolumn{7}{|c|}{ Coefficients $^{\mathrm{a}}$} \\
\hline & \multirow{2}{*}{ Model } & \multicolumn{2}{|c|}{$\begin{array}{l}\text { Unstandardized } \\
\text { Coefficients }\end{array}$} & \multirow{2}{*}{$\begin{array}{c}\begin{array}{c}\text { Standardized } \\
\text { Coefficients }\end{array} \\
\text { Beta }\end{array}$} & \multirow{2}{*}{$\mathrm{T}$} & \multirow{2}{*}{ Sig. } \\
\hline & & B & $\begin{array}{l}\text { Std. } \\
\text { Error }\end{array}$ & & & \\
\hline \multirow{3}{*}{1} & (Constant) & 45.310 & 6.537 & & 6.931 & .000 \\
\hline & Kedisiplinan_Guru (X1) & .271 & .070 & .397 & 3.872 & .000 \\
\hline & $\begin{array}{l}\text { Metode_Mengajar_Guru } \\
\text { (X2) }\end{array}$ & .247 & .074 & .342 & 3.334 & .001 \\
\hline
\end{tabular}

Dari hasil penelitan yang diperoleh dengan analisis regresi linier berganda menggunakan program aplikasi SPSS Version 25 for Windows.maka dapat diuraikan sebagai berikut: 1) Konstanta sebesar 45.310 menunjukkan nilai hasil belajar peserta didik sebelum dipengaruhi oleh variabel kedisiplinan dan metode mengajar guru adalah positif. 2) Koefisien $X_{1}=0.271$ menunjukkan peningkatan 1 skor metode mengajar guru akan meningkatkan hasil belajar sebesar 0.271 dengan asumsi variabel-variabel bebas lainnya konstan. Koefisien bernilai positif artinya terjadi pengaruh positif antara kedisiplinan guru dengan hasil belajar peserta didik, semakin tinggi tingkat kedisiplinan guru maka semakin meningkat hasil belajar peserta didiknya.3) Koefisien $\mathrm{X}_{2}=0.247$ menunjukkan peningkatan 1 skor metode mengajar guru akan meningkatkan hasil belajar peserta didik sebesar 0.247 dengan asumsi variabel-variabel bebas lainnya konstan. Koefisien bernilai positif artinya terjadi pengaruh positif antara metode mengajar guru dengan hasil belajar peserta didik, semakin berpengalaman penerapandan penggunaan metode mengajar guru maka semakin meningkat hasil belajar peserta didiknya.

Untuk Uji T pada penelitian ini digunakan untuk menguji apakah variabel independen berpengaruh secara signifikan terhadap variabel dependen. Dalam tabel spss di atas di ketahui bahwa: 1) Hipotesis pertama pada penelitian ini adalah kedisiplinan guru berpengaruh positif dan signifikan terhadap hasil belajar. Berdasarkan hasil uji regresi berganda pada tabel 4.9 diatas untuk pengaruh kedisiplinan guru (X1) terhadap 
hasil belajar (Y) diketahui bahwa koefisien $\beta$ kedisiplinan guru bernilai positif sebesar 0.271 dan nilai thitung $>\mathrm{t}$ tabel yaitu sebesar $3.872>1.998$ dengan tingkat signifikansi $0.000<0.05$, hal ini menunjukkan bahwa kedisiplinan guru berpengaruh signifikan terhadap hasil belajar peserta didik. sehingga dapat disimpulkan bahwa H1 diterima yang berarti terdapat pengaruh antara variabel X1 terhadap variabel Y. 2) Hipotesis kedua pada penelitian ini adalah metode mengajar guru berpengaruh positif dan signifikan terhadap hasil belajar. Berdasarkan hasil uji regresi berganda pada tabel 4.9 diatas untuk pengaruh metode mengajar guru (X2) terhadap hasil belajar (Y) diketahui bahwa koefisien $\beta$ kedisiplinan guru bernilai positif sebesar 0.247 dan nilai $\mathrm{t}$ hitung $>\mathrm{t}$ tabel yaitu sebesar $3.334>1.998$ dengan tingkat signifikansi $0.001<0.05$, hal ini menunjukkan bahwa metode mengajar guru berpengaruh signifikan terhadap hasil belajar peserta didik. sehingga dapat disimpulkan bahwa $\mathrm{H} 2$ diterima yang berarti terdapat pengaruh antara variabel X2 terhadap variabel Y.

Selanjutnya perolehan data analisis koefisien determinasi untuk mengetahui seberapa besar sumbangan atau kontribusi variabel independen terhadap variabel dependen. Dilihat pada tabel 4.11 di atas dapat diketahui bahwa R Square atau koefisien determinasi sebesar 0.300, dan nilai Adjusted R Square sebesar 0.279 - 27.9\% artinya sumbangan hasil belajar peserta didik terhadap kedisplinan dan metode mengajar guru sebesar $27.9 \%$. sedangkan sisanya $72.1 \%$.

Berdasarkan hasil pembahasan yang diperoleh dari analisis regresi linier melalui program aplikasi SPSS versi 25 for windows dalam rangka untuk mengetahui tinggi atau rendahnya pengaruh antara variable $\mathrm{X} 1$ dan $\mathrm{X} 2$ terhadap variabel $\mathrm{Y}$. maka dipaparkan dengan penjelasan bahwa jika kedisiplinan guru tinggi dan metode mengajar guru rendah belum tentu akan menghasilkan hasil belajar yang optimal.Begitu sebaliknya jika kediplinan guru rendah dan metode mengajar guru tinggi belum tentu juga akan menghasilkan hasil belajar yang optimal.Maka dapat disimpulkan kedisiplinan guru dan metode mengajar guru sangatlah erat hubungannya jika di lihat pada tabel 4.10 yang menyatakan pengaruh kedisiplinan guru (X1) dan metode mengajar guru (X2) secara simultan terhadap hasil belajar peserta didik (Y) bahwa berpengaruh signifikan.

\section{SIMPULAN DAN SARAN}

Berdasarkan hasil pembahasan penelitian tentang kedisiplinan dan metode mengajar guru tehadap hasil belajar peserta didik pada mata pelajaran sosiologi kelas XI IPS di MA N 1 Situbondo dapat ditarik kesimpulan sebagai berikut : 1) Ada pengaruh kedisiplinan guru terhadap hasil belajar peserta didik pada mata pelajaran sosiologi kelas XI IPS di MA Negeri 1 Situbondo tahun pelajaran 2018/2019. 2) Ada pengaruh metode mengajar guru terhadap hasil belajar peserta didik pada mata pelajaran sosiologi kelas XI IPS di MA Negeri 1 Situbondo tahun pelajaran 2018/2019.

Berdasarkan hasil kesimpulan penelitian di atas, berikut ini akan dikemukakan beberapa saran, yaitu : 1) Sebaiknya, guru lebih bersinergi lagi dalam mendidik peserta didik untuk meningkatkan kedisplinan dan hasil belajar peserta didik dalam belajar. 
Guru dapat memberikan ketegasan pada peserta didik yang kurang disiplin dan memberikan hadiah serta pujian pada peserta didik yang lebih disiplin dalam belajar supaya dapat memotivasi dan sebagai contoh bagi peserta didik yang lain untuk lebih disiplin dalam menjalankan tugasnya sebagai pelajar. Guru hendaknya menegur orang tua dari peserta didik untuk mengingatkan anaknya dan mengarahkan anaknya supaya disiplin dalam mengerjakan tugas maupun dalam waktu belajar. 2) Guru juga harus memperhatikan dalam memilih dan mengaplikasikan metode yang tepat digunakan dalam pembelajaran. Tentunya guru harus melihat terlebih dahulu kecocokan antar metode dan cara belajar peserta didik. Metode mengajar yang baik adalah metode yang berdasarkan dengan kemampuan peserta didiknya, tujuan pembelajaran, situasi pembelajaran, fasilitas dan kemampuan guru itu sendiri. Contoh metode mengajar yang cocok dengan pembelajaran sosiologi yaitu dengan dibuat berkelompok ataupun dengan metode mengajar dengan media games, maka peserta didik akan lebih senang dalam melakukan pembelajaran sehingga lebih memperhatikan pelajaran. Selain itu metode mengajar media games ini dapat mengasah kemampuan cara berfikir kritis peserta didik dalam menanggapi dan menjawab pertanyaan secara cepat dan tepat sehingga memungkinkan adanya partisipasi aktif dan bersifat kempetisi menang dan kalah untuk peserta didik dalam belajar.

\section{REFERENSI}

Akbar, Rofiq Faudy. (2014). Pengaruh Metode Mengajar Guru Dan Kemandirian Belajar Terhadap Prestasi Belajar Siswa.Vol. 8, No. 1.

Husamah (2016).Belajar dan Pembelajaran.

Ishlacha.(2012). Pengaruh Kedisiplinan Guru Dalam Mengajar Terhadap Hasil Belajar Siswa.Skripsi.

Khasanah, Umi. (2012). Pengaruh Persepsi Siswa Tentang Metode Mengajar Guru Dan

Disiplin Belajar Terhadap Prestasi Belajar Akuntansi Siswa Kelas X. Vol. 10, No. 2.

Maruya, Siti. (2016). Pengaruh Kedisiplinan Guru Mengajarterhadap Peningkatan Motivasi Dan Hasil Belajar Siswa.Vol. 1, No. 2.

Rosana, Lukas Nana. (2014). Pengaruh Metode Pembelajaran Dan Kemampuan Berfikir Kritis Terhadap Hasil Belajar Sejarah Siswa.Vol. 3, No. 1.

Saroh, Miss Tasmin. (2015). Pelaksanaan Metode Ceramah Dan Diskusi Kelompok Dalam Meningkatkan Efektifitas Pembelajaran.Skripsi.

Septiana, Anisa. (2016). Hubungan Gaya Belajar Dan Persepsi Siswa Tentang Metode Mengajar Guru Terhadap Prestasi Belajar.Vol. 4, No. 2.

Sriyadi.(2013). Pengaruh Metode Mengajar Dan Sumber Belajar Terhadap Prestasi Belajar.Skripsi.

Sugiyono.(2010). Metode Penelitian Kuantitatif, Kualitatif Dan R\&D.

Sujarwanto, Imam. (2013). Upaya Meningkatkan Kedisiplinan Guru Dalam Kehadiran Mengajar Di Kelas.Vol. 1, No. 1.

Yulinda, Farina Riski. (2016). Peranmetode Mengajar Dalam Pembelajaran IPS.Skripsi. 